Syntax Literate : Jurnal Ilmiah Indonesia p-ISSN: 2541-0849 e-ISSN : 2548-1398

Vol. 4, No. 9 September 2019

\title{
PENGARUH PENDAPATAN USAHA DAN BIAYA OPERASIONAL TERHADAP LABA BERSIH SURVEY PADA PERUSAHAAN JASA SUB SEKTOR TRANSPORTASI YANG TERDAFTAR DI BURSA EFEK INDONESIA
}

\section{Yelsha Dwi Pasca}

Program Studi Manajemen STIE STMY Majalengka

Email: yelshadwipasca@gmail.com

\begin{abstract}
Abstrak
Tujuan penelitian ini adalah untuk mengetahui pengaruh pendapatan usaha dan biaya operasional terhadap laba bersih, survei pada perusahaan jasa sub sektor transportasi yang terdaftar di Bursa Efek Indonesia. Berdasarkan uji hipotesis dapat disimpulkan bahwa terdapat pengaruh yang signifikan antara pendapatan usaha dan biaya operasional terhadap laba bersih pada perusahaan jasa sub sektor transportasi yang terdaftar di Bursa Efek Indonesia. Dimana pendapatan usaha dan biaya operasional mempunyai hubungan dengan laba bersih yang sangat kuat dan berbanding lurus, artinya ketika pendapatan usaha dan biaya operasional meningkat maka laba bersih pun akan mengalami peningkatan. Saran bagi perusahaan sebaiknya terus meningkatkan pendapatan usaha agar mendapatkan laba bersih yang maksimal. Karena apabila pendapatan usaha terus meningkat diiringi dengan peningkatan laba bersih maka investor akan tertarik untuk berinvestasi di emiten tersebut. Sebaiknya mengeluarkan biaya operasional seminimal mungkin agar mendapatkan laba bersih yang maksimal. Bila pemakaian biaya operasional tinggi maka laba bersih pun akan menurun dan para investor akan berfikir beberapa kali untuk berinvestasi di emiten tersebut.
\end{abstract}

Kata kunci : Pendapatan usaha, biaya operasional, laba bersih

\section{Pendahuluan}

Keberadaan perusahaan baik itu perusahaan nasional maupun swasta mendorong usaha pemerintah dalam meningkatkan perkembangan ekonomi secara keseluruhan (Kamaludin, 2017). Perusahaan perlu memperhatikan pendapatan yang diterima dan pengeluaran yang dilakukan selama kegiatan operasi berlangsung agar perusahaan dapat menghasilkan laba yang diinginkan demi keberlangsungan usahanya. Jika pendapatan terlalu besar dari beban maka perusahaan akan memperoleh laba dan sebaliknya jika pendapatan lebih kecil dari biaya yang dikeluarkan maka perusahaan akan mengalami kerugian. Karena laporan keuangan digunakan oleh berbagai pihak, baik pihak intern maupun pihak ekstern untuk 
pengambilan keputusan dimasa yang akan datang, maka pendapatan dan beban perlu diperhatikan.

Dalam menghadapi persaingan yang semakin ketat dalam dunia bisnis mengharuskan pihak manajemen perusahaan untuk membuat strategi-strategi yang lebih baik dari perusahaan lain Untuk menjaga kesinambungan hidup perusahaan dalam menghadapi persaingan yang ketat tersebut, diperlukan penanganan dan pengelolaan yang baik dan teratur. Perusahaan adalah suatu lembaga atau instansi yang salah satu kegiatannya bergerak dalam bidang perekonomian dan merupakan satu kesatuan teknis ekonomi tempat terjadinya proses produksi dan pemberian jasa (Ridwan, 2010). Setiap perusahaan pada dasarnya memiliki berbagai tujuan yang berbeda-beda. Tujuannya adalah meningkatkan keuntungan, meningkatkan produktivitas karyawan, meningkatkan kepuasan dan pembinaan karyawan, dan yang paling utama adalah bagaimana perusahaan menghasilkan laba sebesar besarnya

Penilaian kinerja keuangan dapat digunakan untuk mengetahui seberapa besar keuntungan perusahaan dengan membandingkan hasil laba pada tahun tertentu dengan laba tahun-tahun sebelum dan sesudahnya. Dengan diketahuinya kesulitan keuangan sedini mungkin, maka pihak perusahaan dapat mengambil langkah-langkah bagaimana untuk memperbaiki kinerja perusahaan agar dapat meningkatkan laba di masa yang akan datang. Agar diperoleh laba sesuai dengan yang dikehendaki, perusahaan perlu menyusun perencanaan laba yang baik. Hal tersebut ditentukan oleh kemampuan perusahaan untuk memprediksi kondisi usaha pada masa yang akan datang yang penuh ketidakpastian, serta mengamati kemungkinan faktor-faktor yang dapat mempengaruhi laba. Dalam hal ini, laba bersih merupakan suatu ukuran keseluruhan profitabilitas perusahaan yang dapat digunakan untuk mengevaluasi apakah manajemen telah mendapatkan imbalan yang memadai dari penggunaan asset yang dikuasainya. Bagi perusahaan pada umumnya usahanya lebih diarahkan untuk mencapai laba bersih yang maksimal sehingga ukuran tersebut menjadi jaminan bagi sebuah perusahaan untuk dapat beroperasi secara stabil.

Di pasar saham, perusahaan yang telah go public dikelompokan ke dalam beberapa sektor. Perusahaan Jasa sub sektor Transportasi merupakan salah satu bidang yang menjanjikan, dilihat dari peningkatan penggunaan kendaraan dan penggunaan sarana umum membuat perusahaan sub sektor Transportasi akan semakin berkembang. 
Apalagi, sekarang telah diadakannya program mobil murah oleh pemerintah dampaknya meningkatnya kepemilikan mobil pribadi yang tentunya juga akan meningkatkan penggunaan mobil pribadi di jalan yang berakibat pada meningkatnya kepadatan lalu lintas, meningkatkanya konsumsi BBM, peminat angkutan umum akan semakin berkurang, dominasi angkutan pribadi pada angkutan lebaran akan semakin meningkat. Hal ini semakin menegaskan bahwa investasi di sektor ini termasuk salah satu investasi yang cukup menjanjikan.

Kondisi di lapangan ditemukan penurunan laba bersih seperti yang dikemukakan oleh Adityamarwan selaku Direktur Utama PT Jasa Marga (Persero) Tbk mengatakan bahwa beberapa emiten penyedia infrastruktur jalan tol mengalami penurunan laba bersih, salah satunya PT Jasa Marga Tbk (JSMR) mencatat laba bersih sepanjang 2013 sebesar Rp 1,33 triliun. Laba bersih tersebut turun 18,75\% dari perolehan tahun sebelumnya sebesar Rp 1,60 triliun

Laba Bersih dapat dipengaruhi oleh beberapa faktor diantaranya adalah pendapatan. Pendapatan yaitu arus masuk atau peningkatan nilai aset dari suatu entity atau penyelesaian kewajiban dari entity atau gabungan dari keduanya selama periode tertentu yang berasal dari penyerahan/ produksi barang, pemberian jasa atas pelaksana kegiatan lainnya yang merupakan kegiatan utama perusahaan yang sedang berjalan (Sipangkar, 2009). Perusahaan perlu memperhatikan pendapatan yang diterima dan pengeluaran yang dilakukan selama kegiatan operasi berlangsung agar perusahaan dapat menghasilkan laba yang diinginkan demi keberlangsungan usahanya. Hal Tersebut didukung oleh penelitian yang dilakukan oleh (Siregar, 2006) bahwa semakin besar pendapatan usaha yang didapat perusahaan maka akan semakin besar laba keuntungan yang didapat oleh perusahaan. (KERAMIK, 2014) Namun kondisi dilapangan ditemukan kenaikan pendapatan usaha tidak diiringi dengan kenaikan laba bersih. Seperti yang dikemukakan oleh Adityamarwan selaku Direktur Utama PT Jasa Marga (Persero) Tbk mengatakan bahwa Emiten penyedia infrastruktur jalan tol mengalami kenaikan pendapatan usaha menjadi Rp 10,29 triliun dari tahun sebelumnya $\mathrm{Rp}$ 9,07 triliun. Sedangkan laba bersih sepanjang 2013 sebesar Rp 1,33 triliun. Laba bersih tersebut turun $18,75 \%$ dari perolehan tahun sebelumnya sebesar Rp 1,60 triliun. Hal ini diindikasikan karena adanya kenaikan biaya operasional. 
Selain pendapatan, biaya merupakan faktor yang sangat penting dalam setiap perusahaan, baik itu perusahaan yang bergerak dibidang jasa maupun perusahaan manufaktur, dan perhitungannya pun harus dilakukan se-efesien dan se-efektif mungkin. Seperti halnya biaya operasional yaitu biaya-biaya yang dikeluarkan oleh perusahaan untuk menjalankan aktivitas perusahaan guna mencapai tujuan dari perusahaan tersebut. Biaya operasional dapat digunakan sebagai alat untuk meningkatkan profitabilitas yang diupayakan oleh perusahaan. Biaya operasi diharapkan dapat digunakan dan mengalolasikan sumber daya yang dimiliki yang efektif dan efisien. Biaya yang dikeluarkan oleh perusahaan dalam beroperasi perlu dikendalikan sebaik- baiknya, karena walaupun operasional dapat berjalan dengan lancar dan baik namun apabila tidak didukung dengan usaha untuk dapat menekan biaya operasional serendah-serendahnya akan berakibat naiknya biaya operasional. Tingginya biaya operasi akan membuat laba turun, begitu juga jika nilai biaya operasi rendah maka, laba akan naik. Jadi untuk memperoleh laba yang tinggi perlu diperhatikan biaya- biaya yang dikeluarkan dan mengendalikannya secara efektif, selain itu perusahaan dapat mencapai laba sesuai dengan yang ingin dicapainya. Menurut Agung Salim selaku Direktur Operasi PT Citra Marga Nusaphala Persada Tbk (CMNP) mengungkapkan biaya operasional pada tahun 2013 meningkat hingga empat kali lipat akibat banyaknya angkutan berat yang overload melintas. Tetapi dengan kenaikan biaya operasional tersebut laba bersih PT Cipta Marga Nusaphala Persada Tbk (CMNP) tidak mengalami penurunan. Hal ini diindikasikan karena adanya penurunan pendapatan usaha

\section{Metode Penelitian}

Penelitian ini dilakukan dengan metode eksperimen semu (quasi eksperiment). Menurut (Prof Dr Sugiyono, 2010) populasi adalah wilayah generalisasi yang terdiri atas objek atau subjek yang mempunyai kualitas dan karakteristik tertentu yang ditetapkan oleh peneliti untuk dipelajari kemudian ditarik kesimpulannya.Berdasarkan pada pengertian diatas, yang menjadi populasi sasarannya adalah perusahaan jasa sub sektor transportasi yang terdaftar di Bursa Efek Indonesia dari tahun 2013 sampai dengan tahun 2017.

Menurut (P D Sugiyono, 2013) memberikan pengertian sampel adalah bagian dari jumlah dan karakteristik yang dimiliki oleh populasi tersebut. Penentuan jumlah 
sampel yang akan diolah dari jumlah populasi harus dilakukan dengan teknik pengambilan sampling yang tepat. Adapun teknik pengambilan sampel yang digunakan dalam penelitian ini adalah nonprobability sampling (purposive sampling). Menurut ( $\mathrm{P}$ D Sugiyono, 2013) sampling jenuh atau sensus adalah teknik penentuan sampel bila semua anggota populasi digunakan sebagai sample. Penentuan sampel dalam penelitian ini adalah laporan keuangan 3 tahun terakhir pada perusahaan yang terdaftar di bursa efek indonesia dari tahun 2013 - 2017.

Metode yang digunakan yaitu analisis jalur (path analysis) yang digunakan untuk menguji pengaruh pendapatan usaha, biaya operasional terhadap laba bersih. Adapun model analisis jalur dari penelitian ini dapat dirumuskan sebagai berikut:

Persamaan Jalur Sub Struktur Pertama

$$
\mathrm{X}=\rho \mathrm{X} 2 \mathrm{X} 1 \mathrm{X} 1+\varepsilon 1
$$

Persamaan Jalur Sub Struktur Kedua

$$
\mathrm{Y}=\rho \mathrm{YX} 1 \mathrm{X} 1+\rho \mathrm{YX} 2 \mathrm{X} 2+\varepsilon 2
$$

Keterangan :

$\mathrm{X} 1=$ Pendapatan Usaha

$\mathrm{X} 2=$ Biaya Operasional

$\mathrm{Y} \quad=$ Laba Bersih

$\varepsilon \quad=$ Error varian/Pengaruh faktor lain

\section{Hasil dan Pembahasan}

1. Hasil Penelitian

a. Pengaruh Pendapatan Usaha Terhadap Laba Bersih

Diperoleh informasi bahwa nilai korelasi (R) yang diperoleh antara pendapatan usaha dengan laba bersih pada perusahaan jasa sub sektor transportasi yang terdaftar di Bursa Efek Indonesia periode 2013-2017 adalah sebesar 0,729. Nilai 0,729 menurut (Prof Dr Sugiyono, 2010) tergolong hubungan yang kuat dengan nilai positif. Sehingga dapat disimpulkan bahwa terdapat hubungan positif yang kuat antara pendapatan usaha dengan laba bersih, dimana semakin tinggi pendapatan usaha maka akan diikuti semakin tingginya laba bersih pada perusahaan jasa sub sektor transportasi yang terdaftar di Bursa Efek Indonesia periode 2013-2017. 
Pengaruh langsung dari pendapatan usaha (X1) terhadap laba bersih (Y) sebesar $21,44 \%$ dan pengaruh tidak langsung melalui biaya operasional (X2) sebesar $10,60 \%$ sehingga total pengaruh langsung terhadap laba bersih (Y) sebesar $51,47 \%$.

Dari hasil perhitungan diperoleh nilai thitung untuk pendapatan usaha (X1) sebesar 4,017 dengan nilai ttabel sebesar 2,052. Dikarenakan nilai thitung lebih besar dari nilai ttabel $(4,017>2,052)$ maka H0 tolak, artinya pendapatan usaha berpengaruh signifikan terhadap laba bersih pada perusahaan jasa sub sektor transportasi yang terdaftar di Bursa Efek Indonesia periode 2013- 2017.

b. Pengaruh Biaya Operasional Terhadap Laba Bersih

Diperoleh informasi bahwa nilai korelasi $(\mathrm{R})$ yang diperoleh antara biaya operasional dengan laba bersih pada perusahaan jasa sub sektor transportasi yang terdaftar di Bursa Efek Indonesia periode 2013-2017 adalah sebesar 0,682. Nilai 0,682 menurut (Prof Dr Sugiyono, 2010) tergolong hubungan yang kuat dengan nilai negatif. Sehingga dapat disimpulkan bahwa terdapat hubungan negatif yang kuat antara biaya operasional dengan laba bersih, dimana semakin tinggi biaya operasional maka akan diikuti dengan menurunnya laba bersih pada perusahaan jasa sub sektor transportasi yang terdaftar di Bursa Efek Indonesia periode 2013-2017.

Pengaruh langsung dari dari biaya operasional (X2) terhadap laba bersih (Y) adalah sebesar $16,30 \%$ dan pengaruh tidak langsung melalui pendapatan usaha (X1) sebesar $11,70 \%$ sehingga total pengaruh langsung terhadap laba bersih (Y) sebesar 26,0\%.Artinya variabel Biaya Operasional secara parsial mempunyai pengaruh terhadap laba bersih sebesar 28,00\%. Dari hasil perhitungan diperoleh nilai thitung untuk biaya operasional (X2) sebesar 3,443 dengan nilai ttabel sebesar 2,052. Dikarenakan nilai thitung lebih besar dari nilai ttabel $(3,433>2,052)$ maka H0 tolak, artinya biaya operasional berpengaruh signifikan terhadap laba bersih pada perusahaan jasa sub sektor transportasi yang terdaftar di Bursa Efek Indonesia periode 2013-2017.

c. Pengaruh Pendapatan Usaha dan Biaya Operasional Terhadap Laba Bersih

Diperoleh informasi bahwa nilai korelasi (R) yang diperoleh antara pendapatan usaha dengan biaya operasional pada perusahaan jasa sub sektor 
transportasi yang terdaftar di Bursa Efek Indonesia periode 2013-2017 adalah sebesar 0,570. Nilai 0,570 menurut (Prof Dr Sugiyono, 2010) tergolong hubungan yang sedang dengan nilai positif. Sehingga dapat disimpulkan bahwa terdapat hubungan positif yang kuat antara pendapatan usaha dengan biaya operasional, dimana semakin tinggi pendapatan usaha maka akan diikuti dengan seemakin tingginya biaya operasional pada perusahaan jasa sub sektor transportasi yang terdaftar di Bursa Efek Indonesia periode 2013-2017.

Berdasarkan hasil penelitian diketahui bahwa variabel pendapatan usaha dan biaya operasional berpengaruh positif terhadap laba bersih dengan kontribusi pengaruh sebesar 53\% sedangkan sisanya $47 \%$ merupakan faktor lain diluar pendapatan usaha dan biaya operasional.

Dari hasil perhitungan diperoleh nilai thitung untuk pendapatan usaha dan biaya operasional (X1X2) sebesar 17,739 dengan nilai ttabel sebesar 3,354. Dikarenakan nilai thitung lebih besar dari nilai ttabel $(17,739>3,354)$ maka H0 tolak, artinya pendapatan usaha dan biaya operasional berpengaruh signifikan terhadap laba bersih pada perusahaan jasa sub sektor transportasi yang terdaftar di Bursa Efek Indonesia periode 2013-2017.

\section{Pembahasan}

a. Analisis Pengaruh Pendapatan Usaha Terhadap Laba Bersih

Berdasarkan hasil penelitian diketahui bahwa variabel pendapatan usaha berpengaruh positif terhadap laba bersih dengan kontribusi pengaruh sebesar $51,47 \%$ sedangkan sisanya sebesar $48,53 \%$ merupakan faktor lain yang tidak saya teliti seperti harga jual, volume penjualan, pendapatan bunga. Hubungan positif ini menunjukan bahwa semakin tinggi pendapatan usaha suatu perusahaan maka kemungkinan perusahaan tersebut mendapatkan laba bersih yang akan semakin besar. Penelitian ini mendukung teori yang dikemukakan oleh (Rahardjo, 2000) Faktor utama yang mempengaruhi besar kecilnya laba adalah pendapatan, pendapatan dapat diperoleh dari hasil penjualan barang dagangan perusahaan.

Berdasarkan hasil penelitian memberikan bukti empiris bahwa variabel pendapatan usaha berpengaruh signifikan terhadap laba bersih, dapat dimaknai bahwa semakin tinggi pendapatan usaha yang diperoleh perusahaan maka 
semakin besar pula laba bersih yang diperoleh perusahaan. Penelitian ini kembali mengkomfirmasi jika besar kecilnya laba dipengaruhi oleh pendapatan usaha seperti yg dikemukakan oleh Weygandt etc (2010) bahwa Jika pendapatan melebihi pengeluaran (beban) akan mendapatkan laba, sebaliknya jika pendapatan kurang dari pengeluaran (beban) akan mendapatkan kerugian. Kemudian hal ini juga menguatkan penelitian yang dilakukan oleh Ni Komang tri Utari (2014) yang meneliti Pengaruh pendapatan dan biaya terhadap net income pada lembaga pengkreditan desa (lpd) desa pakraman batumulapan di kecamatan nusa penida menyatakan bahwa Pendapatan berpengaruh signifikan terhadap net income. Adapun fenomena yang terjadi dipenelitian ini diungkapkan oleh Adityamarwan selaku Direktur Utama PT Jasa Marga (Persero) Tbk yang mengatakan bahwa tidak semua perusahaan yang memiliki pendapatan usaha yang meningkat akan mendapatkan laba bersih yang meningkat pula. Salah satunya PT Jasa Marga (Persero) Tbk menurut Adityamarwan hal ini diindikasikan karena adanya peningkatan biaya operasional ataupun faktor - faktor lain yg mendukung menurunnya laba bersih. Penulis melihat bahwa dengan meningkatnya pendapatan usaha seharusnya laba bersih pun ikut meningkat. Tetapi karena ada faktor lain yang mempengaruhi menurunnya laba maka peningkatan pendapatan tidak dapat menaikan laba .

b. Analisis Pengaruh Biaya Operasional Terhadap Laba Bersih

Berdasarkan hasil penelitian diketahui bahwa variabel biaya operasional berpengaruh negatif terhadap laba bersih dengan kontribusi pengaruh sebesar $28 \%$ sedangkan sisanya sebesar $72 \%$ merupakan faktor lain yang tidak saya teliti seperti harga jual, volume penjualan, pendapatan bunga. Hubungan negatif ini menunjukan bahwa semakin tinggi biaya operasional suatu perusahaan maka kemungkinan laba bersih perusahaan tersebut akan menurun. Penelitian ini mendukung teori yang dikemukakan oleh (Jusuf, 2008) Bila perusahaan dapat menekan biaya operasional, maka perusahaan akan dapat meningkatkan laba bersih. Demikian juga sebaliknya, bila terjadi pemborosan biaya (seperti pemakaian alat kantor yang berlebihan) akan mengakibatkan menurunnya net profit. 
Berdasarkan hasil penelitian memberikan bukti empiris bahwa variabel biaya operasional berpengaruh signifikan terhadap laba bersih, dapat dimaknai bahwa semakin tinggi biaya operasional yang dikeluarkan perusahaan maka laba bersih perusahaan tersebut akan menurun. Hal ini menguatkan penelitian yang dilakukan oleh (Pebriyanti, 2013) meneliti Pengaruh Efisiensi Biaya Operasional Terhadap Laba Bersih dengan Perputaran Persediaan Sebagai Variabel Pemoderasi menyatakan bahwa semakin besar biaya operasional maka semakin sedikit laba yang akan diterima. Kemudian hal ini juga menguatkan penelitian yang dilakukan (Wisesa, Zukhri, \& Suwena, 2014) menyatakan bahwa biaya operasional mempunyai pengaruh yang negatif terhadap laba bersih. Artinya semakin besar biaya operasional yang dikeluarkan maka semakin kecil laba bersih yang diperoleh demikian pula sebaliknya semakin kecil biaya operasional yang digunakan maka semakin besar laba bersih yang diperoleh. Adapun fenomena yang terjadi dipenelitian ini diungkapkan oleh Menurut Agung Salim selaku Direktur Operasi PT Citra Marga Nusaphala Persada Tbk (CMNP) yang mengatakan bahwa pada perusahaan tersebut biaya operasional meningkat sebanyak empat kali tetapi dengan kenaikan tersebut tidak menyebabkan menurunnya laba pada perusahaan tersebut. Menurut Agung Salim hal ini diindikasikan karena menurunnya pendapatan usaha. Penulis melihat bahwa dengan meningkatnya biaya operasional seharusnya laba bersih pun menurun. Tetapi karena ada faktor lain yang mempengaruhi meningkatnya laba maka peningkatan biaya operasional tidak dapat menurunkan laba .

c. Pengaruh Pendapatan Usaha dan Biaya Operasional Terhadap Laba Bersih

Berdasarkan hasil penelitian diketahui bahwa variabel pendapatan usaha dan biaya operasional berpengaruh positif terhadap laba bersih dengan kontribusi pengaruh sebesar 53\% sedangkan sisanya $47 \%$ merupakan faktor lain diluar pendapatan usaha dan biaya operasional. Penelitian ini mendukung teori yang dikemukakan oleh (KERAMIK, 2014) bahwa perusahaan perlu memperhatikan pendapatan yang diterima dan pengeluaran yang dilakukan selama kegiatan operasi berlangsung agar perusahaan dapat menghasilkan laba yang diinginkan demi keberlangsungan usahanya. Kemudian hal ini juga 
menguatkan penelitian yang dilakukan oleh (Budi, 2011) menyatakan bahwa biaya operasional berpengaruh signifikan terhadap pendapatan usaha.

\section{Kesimpulan}

1. Pendapatan Usaha berpengaruh Positif signifikan terhadap Laba Bersih pada perusahaan jasa sub sektor transportasi yang terdaftar di Bursa Efek Indonesia periode 2013 - 2017. Dimana pendapatan usaha mempunyai hubungan dengan laba bersih yang sangat kuat dan berbanding lurus, artinya jika pendapatan usaha meningkat maka laba bersih pun akan mengalami peningkatan.

2. Biaya Operasional berpengaruh negatif signifikan terhadap Laba Bersih pada perusahaan jasa sub sektor transportasi yang terdaftar di Bursa Efek Indonesia periode 2013-2017. Dimana biaya operasional mempunyai hubungan dengan laba bersih yang sangat kuat dan berbanding terbalik, artinya ketika biaya operasional meningkat maka laba bersih pun akan mengalami penurunan.

3. Berdasarkan uji hipotesis dapat disimpulkan bahwa terdapat pengaruh yang signifikan antara Pendapatan Usaha dan Biaya Operasional terhadap Laba Bersih pada perusahaan jasa sub sektor transportasi yang terdaftar di Bursa Efek Indonesia periode tahun 2013-2017. Dimana pendapatan usaha dan biaya operasional mempunyai hubungan dengan laba bersih yang sangat kuat dan berbanding lurus, artinya ketika pendapatan usaha dan biaya operasional meningkat maka laba bersih pun akan mengalami peningkatan. 


\section{BIBLIOGRAFI}

Budi, S. (2011). Analisa Pengaruh Biaya Operasional Terhadap Tingkat Pendapatan PT Jasa Marga, Tbk Periode 2006-2010. Fakultas Ekonomi Universitas Gunadarma. Jakarta.

Jusuf, J. (2008). Analisis Kredit untuk Account Officer. Jakarta: PT. Gramedia Pustaka Utama.

Kamaludin, A. (2017). Pengaruh Strategi Promosi Dan Kualitas Produk Terhadap Keputusan Pembelian (Studi Di PT Sarana Panca Karya Nusa Distributor Kabupaten Majalengka). Syntax Literate; Jurnal Ilmiah Indonesia, 2(3), 1-27.

KERAMIK, P. (2014). PENGARUH PENDAPATAN USAHA DAN BEBAN OPERASIONAL TERHADAP LABA BERSIH PADA PERUSAHAAN KIMIA DAN KERAMIK, PORSELIN \& KACA YANG TERDAFTAR DI BURSA EFEK INDONESIA PERIODE 2008-2012 MEIZA EFILIA. 100462201068.

Pebriyanti, N. K. S. (2013). Pengaruh Kompensasi Terhadap Kepuasan Kerja Karyawan PT. Columbus Megah Sarana Cabang Denpasar Tahun 2012. Jurnal Pendidikan Ekonomi Undiksha, 3(1).

Rahardjo, B. (2000). Memahami Laporan Keuangan Untuk Manajer Non Keuangan. Yogyakarta: Andi Offset.

Ridwan, S. (2010). Analisis biaya operasional dan pengaruhnya terhadap tingkat laba bersih pada PDAM Kota Bandung. Skripsi. Bandung: Fakultas Ekonomi Universitas Komputer Indonesia.

Sipangkar, E. D. (2009). Pengaruh Perputaran Persediaan Terhadap Tingkat Profitabilitas Perusahaan Pada Perusahaan Otomotif yang Terdaftar di Bursa Efek Indonesia.

Siregar, F. dan H. S. (2006). Pengaruh Faktor Internal Bank terhadap Volume Kredit Bank Yang Go Public Di Indonesia. Jurnal Akuntansi 6 USU.

Sugiyono, P D. (2013). Metode Penelitian Manajemen. Bandung: Alfabeta, CV.

Sugiyono, Prof Dr. (2010). Metode penelitian pendidikan. Pendekatan Kuantitatif.

Wisesa, I. W. B., Zukhri, A., \& Suwena, K. R. (2014). Pengaruh Volume Penjualan Mente Dan Biaya Operasional Terhadap Laba Bersih Pada Ud. Agung Esha Tahun 2013. Jurnal Pendidikan Ekonomi Undiksha, 4(1). 